\title{
Author Correction: A mechanism for CO regulation of ion channels
}

\author{
Sofia M. Kapetanaki ${ }^{1}$, Mark J. Burton², Jaswir Basran², Chiasa Uragami ${ }^{3}$, Peter C. E. Moody (1) ${ }^{2}$, \\ John S. Mitcheson ${ }^{2}$, Ralf Schmid², Noel W. Davies², Pierre Dorlet (1D ${ }^{3}$, Marten H. Vos (D) ${ }^{4}$, \\ Nina M. Storey ${ }^{2} \&$ Emma Raven (10 ${ }^{1}$
}

Correction to: Nature Communications https://doi.org/10.1038/s41467-018-03291-Z; published online 02 March 2018

The originally published version of this article contained an error in the subheading 'Heme is required for CO-dependent channel activation', which was incorrectly given as 'Hame is required for CO-dependent channel activation'. This has now been corrected in both the PDF and HTML versions of the Article.

Published online: 17 August 2018

Open Access This article is licensed under a Creative Commons Attribution 4.0 International License, which permits use, sharing, adaptation, distribution and reproduction in any medium or format, as long as you give appropriate credit to the original author(s) and the source, provide a link to the Creative Commons license, and indicate if changes were made. The images or other third party material in this article are included in the article's Creative Commons license, unless indicated otherwise in a credit line to the material. If material is not included in the article's Creative Commons license and your intended use is not permitted by statutory regulation or exceeds the permitted use, you will need to obtain permission directly from the copyright holder. To view a copy of this license, visit http://creativecommons.org/licenses/by/4.0/.
\end{abstract}

(c) The Author(s) 2018

\footnotetext{
${ }^{1}$ Department of Chemistry and Leicester Institute of Structural and Chemical Biology, University of Leicester, Leicester LE1 7RH, England. ${ }^{2}$ Department of Molecular and Cell Biology and Leicester Institute of Structural and Chemical Biology, University of Leicester, Leicester LE1 9HN, England. ${ }^{3}$ Institute for Integrative Biology of the Cell (I2BC), CEA, CNRS, Univ. Paris-Sud, Université Paris-Saclay, 91198 Gif-sur-Yvette cedex, France. ${ }^{4}$ LOB, Ecole Polytechnique, CNRS, INSERM, Université Paris-Saclay, 91128 Palaiseau Cedex, France. Correspondence and requests for materials should be addressed to N.M.S. (email: ns140@le.ac.uk) or to E.R. (email: emma.raven@le.ac.uk) These authors contributed equally: Sofia M. Kapetanaki, Mark J. Burton.
} 